\title{
BÓDI ZOLTÁN
}

\section{A szóbeliség kifejeződése az internetes kommunikációban}

Az Interneten megjelenő szövegek - az írásbeliség megjelenése óta fennálló természetes igények kielégítésére törekedve - egyre inkább multimediális jelleget öltenek. A vizuális elemekre is alkalmazható hiperlinkek segítségével a multimediális kommunikátumok egységes szerkezetbe tagolódnak a világhálón. Mindez a Gutenberg-galaxist felváltó poszt-literalitás jelenségeként értékelhető. Az Interneten folyó kommunikáció gyorsaságával, szerkesztetlen párbeszédstruktúrájával és sajátosan alkalmazott szimbólumaival a spontán szóbeli diskurzushoz közelít. Ez utóbbiakat a tanulmány szerzője online kérdőíves módszerrel vizsgálta a hazai felhasználók körében, s az eredmények alapján részletesen elemzi az úgynevezett mosolykódok különféle alkalmazási módjait.

\section{Szerzői információ:}

\section{Bódi Zoltán}

Nyelvész, az ELTE BTK Magyar Nyelvtudományi és Finnugor Intézetének fôiskolai docense. Kutatási területe az Internet és az informatika nyelvhasználata, „A világháló nyelve” címmel 2004-ben jelent meg önálló kötete. 1992 óta folyamatosan publikál önálló tanulmányokat. Szaktudományos munkákat szerkeszt, elôadásokat tart szakmai konferenciákon, rendszeresen végez szakértői tevékenységet fốként a Magyar Rádió különbözổ músoraiban, valamint a televíziókban és az informatikai szaksajtóban. 1999 óta az Információs Társadalom- és Trendkutató Központ munkatársa. Tagja a Magyar Nyelvtudományi Társaságnak, a Magyar Alkalmazott Nyelvészek és Nyelvtanárok Egyesületének, s alapító tagja az ELTE Nyelvstratégiai Kutatócsoportjának. PhD fokozatát 2003-ban szerezte meg, disszertációjának témája: Internetezők és internetes nyelohasználat a magyarban.

Így hivatkozzon erre a cikkre:

Bódi Zoltán. „A szóbeliség kifejeződése az internetes kommunikációban”. Információs Társadalom IV, 1. szám (2004): 26-38. https://dx.doi.org/10.22503/inftars.IV.2004.1.2

A folyóiratban közölt müvek

a Creative Commons Nevezd meg! - Ne add el! - Így add tovább! 4.0 Nemzetközi Licenc feltételeinek megfelelöen használhatók. 
Bód i Z oltán

\section{A szóbeliség kifejeződése az internetes kommunikációban}

\section{Bevezetés}

Az Interneten az írás és a beszéd kommunikációs múfajainak sajátos keveredése figyelhetô meg: a fejlesztések ellenére még mindig fóként írásos formában megjelenő közlemények - a különféle internetes múfajokban különbözőképpen, de határozottan - a beszélt nyelv bizonyos sajátosságai felé közelítenek. A világhálón az írásbeliség és a szóbeliség sajátos viszonya jelenik meg (Crystal, 2001:24). Különösen a gyors, erôsen interaktív kommunikációt lehetővé tevő múfajokban, vagyis az elektronikus levelezésben és a csevegőfórumokon figyelhető meg ez a jelenség.

\section{A hipermédia korszaka}

Az elektronikus média korszakának a poszt-Gutenberg galaxis nevet is adhatjuk. Az elektronikus média - amelynek része az Internet is - nagy újdonságot hoz a megismerô, felfedezố szándékú gondolkodásba (Harnad, 1990). ${ }^{1}$ A gyors gondolkodás és reagálás az Internet legjellegzetesebb újdonsága, ami az internetes kommunikációs mûfajokban már alapkövetelménnyé válik (Dyson, 1998:87). Gondolkodásmódunk változik, s ezért az írásbeliség és a múfajiság is átalakul. Érdemes azonban szem elốtt tartani Kis Ádám megállapítását, miszerint az elektronikus médiában kialakuló új kommunikációs formák nem szüntetik meg a Gutenberg-galaxist, hanem csak kiegészítik azt, bizonyos tekintetben módosítva a nyomtatott kommunikációs formákat. Ahogy a nyomtatás elterjedésével sem szűnt meg a kézírás, úgy az elektronikus média korszakában sem szúnik meg a könyvnyomtatás (Kis Ádám, 1997). ${ }^{2}$

Nyíri szerint a 19. századtól, amikor már elég fejlett a nyomdatechnika, a kép a szöveg részévé válik. Ezt nevezzük Gottfried Boem nyomán ikonikus forradalomnak (Nyíri, 1996 id. Gottfried Boem, 1995:13). Ekkor azonban még a szövegé a vezető szerep, az új internetes média megjelenésével viszont a kép (akár a mozgókép is) és a hang a közlemény egyenértékư részévé válik, az írás elveszíti vezetố szerepét, s a kultúra a posztliteralitás korszakába lép. „Az ikonikus fordulat a posztliteralitás jelensége.” (Nyíri, 1996:10). A poszt-Gutenberg galaxis jellegzetes vonása a multimedialitás.

http://cogsci.soton.ac.uk/ harnad/Papers/Harnad/harnad90.skywriting.html

http://www.mek.iif.hu/porta/szint/tarsad/nyelvtud/szmtgps.hun 
Az Internet mint kommunikációs médium közegében a szóbeli, a vizuális és az írásbeli kommunikációs csatornák összekapcsolódnak, és megjelenik a multimédia. Michael Heim szerint ez a hipermédia korszaka: az Internet - mivel lehetôvé teszi képek, videófelvételek, hang és animáció egyidejú továbbítását, illetve azonnali elérését - nem lineáris alkotói és befogadói magatartást igénylő médium (Heim, 1997). ${ }^{3}$

Az Internet és azon belül a World Wide Web multimediális jelenség, vagyis az írott szöveggel összekapcsolódó vizualitás és akusztikum ugyanúgy az információk hordozójává válhat, mint a hagyományos nyomtatás.

\section{Az írott beszélt nyelv}

Susan C. Herring (Herring, 1996) a számítógéppel közvetített kommunikációról (CMC: Computer-Mediated Communication) szóló, általa szerkesztett kötetben megjegyzi, hogy a kommunikációnak ez a fajtája - bár írásos megjelenésű, hiszen az üzeneteket billentyưzet segítségével rögzítik - jobban hasonlít a beszédkommunikációhoz, igen gyors információcserét biztosít, speciális (jórészt rövidítésekre alapozott) szókincse van, és itt a képiség is fontos információhordozó. Mindezek mellett azt is érdemes figyelembe venni, hogy az internetes kommunikációban különböző kommunikációs múfajok ötvözôdnek, s ezért a nyelvhasználat nem homogén (Herring, 1996:3).

Ong három korszakot különít el a kommunikációtörténetben: az elsôdleges szóbeliség (primary orality), az írásbeliség (literacy) és a másodlagos szóbeliség (secondary orality) korszakát (Ong, 1982:136). A másodlagos szóbeliség korszakát Ong a hang rögzítésére és átvitelére szolgáló technikai eszközök (a telefon, a fonográf, majd a rádió és a magnetofon) feltalálásától számítja, amelyek mind térben, mind időben jelentôsen kitágították a szóbeli kommunikáció hatókörét. Ong szerint a másodlagos szóbeliség az 1980-as évekig tart, a televízió széleskörú megjelenése és elterjedése már nem a szóbeliség, hanem a képiség korszaka.

Szépe György is felvázol egy kommunikációs fejlődési sort: szóbeliség, írás, nyomtatás, magánhasænálatú irógép, számitógép, multimédia (Szépe, 1997:78). Ez a fejlődési sor azonban Szépe szerint is csak vázlatosnak tekinthetô, mert hiányoznak belóle az élôszó rögzítési és reprodukálási lehetőségei. Természetes, hogy amint lehetőség nyílt az élőszó rögzítésére és megőrzésére, ez már önmagában is a kultúra hordozójává vált. A megôrzött és reprodukálható szóbeliség szövegei a szóbeliség korszakához képest többé már nem pontatlanok, és már nemcsak az emlékezetünk ôrzi meg az információkat, hanem pontos formában rögzíthetjük a tudást. A Szépe-féle fejlődési sort ki lehet egészíteni egy újabb síkkal: a szóbeliség rögzítésének lehetôvé tételét hozzávetôlegesen arra az idôszakra tehetjük, amikor a magánhasználatú írógépek elterjedtek. A teljesebbé tett sorozat tehát így alakul: šóbeliség, irás, nyomtatás, magánhasználatú irógép, hangfelvétel, asæinkron hangtovábbitás, sæinkron hangtovábbitás, sæámítógép, multimédia.

\footnotetext{
3 http://www.mheim.com/html/docs/vrtea/vrtea.html
} 
Az Interneten folyó kommunikációban megjelenő szövegekre - a hagyományos írott szövegekkel szemben - kevésbé jellemzô a szabályozottság, a normakövetés és a szerkesztettség. Nem egyértelmú, hogy a „posztliterális környezetben” megalkotott, magánjellegư $e$-mail és chat ïzenetek kommunikációs múfaja az írott vagy inkább a beszélt nyelvi kommunikációhoz sorolható-e (Bódi, 1998:179). Az Interneten jelentkezố spontán szövegek köztes kommunikációs múfaját írott beszélt nyelonek nevezhetjük (Bódi, 1998:186). Balázs Géza ugyanezt a jelenséget másodlagos írásbeliségként ismerteti, ô azonban ezt a jelenséget az Internet mellett kiterjeszti a mobiltávközlés sms-szolgáltatásainak, valamint más médiumoknak az írásbeliségére is (Balázs, 2003:149). Az angol nyelvvel foglalkozó nemzetközi kutatások is rávilágítottak már, hogy az Interneten továbbított üzenetek az írott és a beszélt nyelv között helyezkednek el, hiszen a partnerek nem látják és nem is hallják egymást, s ezért ezek a szövegek kissé személytelenebbek is; viszont a világhálón a felhasználók ugyanakkor kifejezetten a spontán beszélt nyelvhez hasonlóan formálják meg szövegeiket (Herring, 1996:4; Collott - Bellmore, 1996:14, 21).

David Crystal szerint a „netnyelv” (Netspeak) mint harmadik típusú médium kombinálja az írásra, a beszédre és elektronikus közvetítésre jellemző elemeket (Crystal, 2001:48).

\section{Az írott beszélt nyelv az internetes interakcióban}

Az Interneten folyó interakciókban - a beszédhez közelítve - kétségbeesett erôfeszítés zajlik arra, hogy a prozódia és a paralingvisztika tárgyköréhez tartozó metakommunikáció hiányosságait sikerüljön pótolni (Crystal, 2001:34). A betúhalmozás, az írásjelhalmozás, a csupa nagybetûs szavak, a ritkítottan szedett szavak, a csillagok vagy szóközi aláhúzások közé foglalt szavak - mind-mind az internetes nyelv köztes múfajiságának jelenségei (Crystal, 2001:35). A - fő́ként az elektronikus levelezésben és a chat fórumokon megjelenô - mosolyszimbólumok, a smiley-k kiválóan alkalmasak a prozódiai és paralingvisztikai elemek, a metakommunikáció pótlására és általában az érzelmek kifejezésére. A smiley-k éppen azért terjedtek el annyira az Interneten, mert a „netnyelv” a gyors, azonnali interakcióhoz, vagyis a beszédhez közelít, s így egyre nagyobb igény merül fel az érzelmek jelzésére is (Crystal, 2001:38). Meg kell azonban jegyezni, hogy a mosolyszimbólumokról csak az adott kontextusban derül ki, hogy pontosan milyen szándékot közvetítenek (Herring, 1996:3; Werry, 1996:52).

A verbális kommunikációt idézô jelek az írott szöveg részévé válnak. A mosolyszimbólumokról számos honlapon tanulmányozhatunk alapos áttekintéseket.

Az e-mailen továbbított levelekben emellett olyan, néhány betúbôl álló, súrített jelentéstartalmú betűszók és rövidítések is előfordulnak, amelyekkel más magyar nyelvú kodifikált szövegben nem találkozunk. Jellemzố példa erre a + jel használata a „meg” igekötő helyett, továbbá a számjegyek felhasználása több betû helyett (5let $=$ ötlet, 660 s $=$ hathatós, $5 / c=5$ perc, 1 pill = egy pillanat). Gyakoriak az angol nyelvú rövidítések is: $T H X=$ thanks (köszönöm), imho = in my humble opinion (szerény véleményem szerint), btw = by the way (apropó, erról jut eszembe), pls = please (kérem, kérlek ), $\operatorname{tnx}=$ thanx (köszi, kösz), CU IRL = see you in real life (találkozunk a valós 
életben - elköszönés olyan helyzetben, amikor az internetes levélváltás után a partnerek személyesen is találkoznak), $A S A P=$ as soon as possible (amilyen gyorsan csak lehet). Ezeknek a rövidítéseknek a használata - amellett, hogy gyorsítja az írott kommunikációt - csoportnyelvi jelenség is lehet, hiszen a gyakorlott internetezôk számára ezek az amerikai-angol mintájú rövidítések, összevonások ismerôsek lehetnek, de az Interneten kívüli írásbeliségben ezek a kódok aligha értelmezhetőek.

Egyre gyakrabban fordul elô az is, hogy az e-mail és chat szövegekben az íráskép és az írásmód a beszélt nyelvi megnyilatkozások fonetikai megjelenését próbálja ábrázolni, tehát az írott szöveg már a megjelenési formájával, a látványával is (a beszélt nyelvre utaló) üzenetet hordoz. Olyan esetekben is alkalmazzák a fonetikai írásmódot, amikor az nem illik a kodifikált, írott szöveghez: aggyál, taníccs + , nyittyuk, majkésóbbcsinájjuk +, asszem, emléxel.

Igen jellemzố a magyar szavak leegyszerúsített vagy divatszerú, sajátos helyesírása: majnem, ijet, uccse, tuggya, szal (szóval), fekünni, pill (pillanat), lejöhecc, mïen, iszni, rencergazda; soxor, emléxik, fexik, yol (jól), kaqkk, muxik (vagyis múködik!). Gyakori jelenség a magyar szavak már említett, számjegyeket és betúket keverô írásmódja is: 6ás, 1szeru, megold6ó, 2séges, 1általán, +öllek!, Lhúz (elhúz), GPn (gépén) stb.

Az elektronikus levelezésben és a chat fórumokon másféle, tipográfiai eszközöket alkalmazó jelölések is előfordulnak: a kiemelendő szavakat gyakran aláhúzással jelölik meg a szó elốtt és után:_könyv_, tudás_. A csupa NAGYBETÚVEL szedett szó vagy akár teljes szöveg erôsen emocionális tartalmat tükröz, az ilyen szövegrészlet a beszédben a kiabálásnak felel meg.

Ezek a jelenségek arra utalnak, hogy az elektronikus levelezés, illetve a csevegő́orumok kommunikációs múfaja a spontán beszédkommunikációhoz közelít. Ez a helyesírás egyaránt fakadhat sietségből, tréfakedvből és csoportnyelvi hatásokból. Annyi azonban bizonyos, hogy ez tudatos nyelvi jelenség (Miklós, 1996).4 Hozzá kell tenni, hogy ez a leegyszerúsített, funkcionális írásmód bizonyos esetekben az anyanyelvi múveltség hiányosságai miatt is felbukkanhat. A tudáshiány miatt, illetve szándékosan elkövetett helyesírási módosítások szétválasztása azonban nehéz, sokszor esetleges.

A csevegőfórumok írásmódjában megfigyelhető továbbá a központozásnak és a mondathatárok jelölésének a hiánya. Rendszeresen elmaradnak a vesszôk, a mondatkezdő nagybetúk és a mondatzáró írásjelek is. A mondatvégi írásjelek csak akkor fordulnak elő többé-kevésbé következetesen, ha emocionális okokból vagy kiemelési céllal halmozzák ôket. Ezek is azt szolgálják, hogy az információáramlás sebessége, a gépelés gyorsasága a lehetô legnagyobb legyen, a legjobban megközelítse a beszélt nyelv tempóját. A csevegôfórumok szövegeit jellemzôen csak annyira formálják meg, hogy az üzenet még könnyen érthető legyen. A mondatkezdő nagybetúk és a tagmondatokat, illetve egyes szavakat a helyesírás szabályai szerint elválasztó vesszôk, valamint a mondatzáró írásjelek mellốzésével az üzenet még egyértelmú maradhat.

\footnotetext{
4 http://www.mek.iif.hu/porta/szint/muszaki/szamtech/wan/kultura/ircnyelv.hun
} 
Simeon J Yates szerint az internetes szövegek modalitása jellemzően a spontán beszélt nyelvhez hasonlít, a szóhasználat inkább írott nyelvi sajátosságokat mutat (Yates, 1996:46). Nem elhanyagolható az a szempont sem, amire Pixie Ferris világít rá: szerinte az internetes írásbeliséget leginkább az egyidejúsége és azonnali interaktivitása közelíti a beszélt nyelvhez (Ferris, 1997).

$\mathrm{Az}$ Internet elektronikus, globális és interaktív médium, s mindezek a jellemzốk kihatnak magára az Internet nyelvére is. Az elektronikus jellegnek az a következménye, hogy a világhálón csak olyan információkat - és csakis olyan formában - tudunk továbbítani, amit az elektronikus médium lehetôvé tesz. Ez azt jelenti, hogy a billentyưzet karakterkészlete meghatározza, hogy mit és milyen formában küldhetünk; a képernyő mérete és az általunk használt számítógépes konfiguráció típusa pedig azt szabja meg, hogy mit és milyen formában láthatunk, mit fogadhatunk be az Interneten keresztül (Crystal, 2001:24). Más szóval: bármennyire közelít is az Internet nyelve a beszélt nyelvhez, mégis az írásbeliség technikai környezetének korlátai között kell maradnia.

\section{A mosolyszimbólumok jelentősége az internetes kommunikációban}

Az Internet és a nyelvhasználat kapcsolatának irodalmában sok sztereotípiát és felületes véleményt találhatunk. Az egyik leggyakoribb téma a mosolyszimbólumok vagy emotikonok használata. Az emotikonok alkalmazását a következőkben annak a kiindulópontnak a szem előtt tartásával kísérelem meg vizsgálat tárgyává tenni, hogy azok az Internet erôsen interaktív múfajaira jellemzô írott beszélt nyelv fontos építôelemei (Bódi, 2004:39).

A gyakran internetezők körében a smiley, a mosolykód közismert szimbólum, ami sûrűn előfordul az Interneten olvasható üzenetekben (vö. pl. Koltay, 1997:94.). A mosolykód az érzelmeket kifejezố metakommunikatív eszközöket, amelyek az írásos szövegekbôl szükségképpen hiányoznak, a billentyưzeten található írásjelekból és egyéb szimbólumokból alkotott képi információ primitív ikonjaival helyettesíti: :-) , :-( . A mosolykód általános, nyelvtôl és kultúrkörtôll függetlenül értelmezhetô ikonikus jel, amely az emberi arcvonásokat, (illetve az azokhoz kapcsolódó emocionális hátteret) próbálja felidézni. Értelmezése világos és mindenki számára egyértelmű lehet.

Konkrét következtetések levonásához elvégeztem egy vizsgálatot. A kutatás törzsanyagát alkotó nyelvi adatok nagy tömegét online kérdôíves módszerrel gyújtöttem össze. Ez a módszer ugyan nem tesz eleget a statisztikai mintavétel szabályainak, de ha egy ilyen felmérést jól megtervezünk, akkor a beérkező nagy mennyiségú nyelvi adat szemiotikai és szociolingvisztikai szempontból egyaránt hasznos új eredményeket hozhat (Márton, 2000:1241; Babbie, 1999:293-294.). A hibás következtetések elkerülése érdekében mindenesetre inkább tartózkodom a számszerú adatok emlegetésétốl, és csak tendenciákra próbálok rámutatni. A vizsgálat tárgyának természetébôl fakad, hogy néhány elem, illetve megállapítás ismétlődik, ám ez az elemzés során elkerülhetetlen, hiszen csak így kaphatunk korrekt, részletes eredményeket.

${ }^{5}$ http://www.december.com/cmc/mag/1997/jun/ferris.html 


\section{Az indulatosság, az elégedetlenség kifejezése}

Megfigyelésem szerint az indulat és az elégedetlenség kifejezésére az internetes kommunikáció során a szöveggel egyenrangú szerepet játszik a smiley-k alkalmazása. Ez megerôsíti azt a nézetet, amely szerint az internetes kommunikáció során a jelek és szimbólumok, $s$ általában a vizuális elemek legalább akkora szerepet játszanak, mint az írott szöveg (vö. pl.: Heim, 1997; Nyíri, 1996. id. Gottfried Boem, 1995:13; Herring, 1996:3; Werry, 1996:52.).

Míg az indulat megjelenítésére használt kifejezôeszközök igen változatosak hiszen a leggyakrabban előforduló emotikon, a >:( is ritkán fordul elő - addig az elégedetlenséget leginkább az egyszerû elemek szimbolizálják: :-( és :/. A negatív érzelmet kifejező alap-emotikonok, a :( és a :-( gyakoriak ezekben a funkciókban. Az indulatosságról úgy tûnik, hogy az ábrázolási (és értelmezési) módja nem egységes, hanem meglehetôsen változatos és kevésbé általános. Feltûnő, hogy a karakterek között gyakran fordul elő az összeráncolt szemöldököt, illetve homlokot szimbolizáló > jel, és a legörbülő szájat jelölő ( jel is, amelyek együtt a >:-( ikont alkotják. Az összeráncolt szemöldököt vagy homlokot szimbolizáló > jel variációjaként elófordul a \} jel használata is, ezzel az ikon a \}:( alakot ölti. Az elégedetlenséget ábrázolja az összevont szemöldököt szimbolizáló $=($ jel is. Észre kell venni, hogy az elégedetlenség kifejezésénél az emotikonok hangsúlyos része a szemöldökön, homlokon megjelenő barázda: $=:-(,>:-\mid\}:,($, ]8- $($.

A válaszadók leggyakrabban elégedetlenségük foka, illetve vérmérsékletük szerint szaporítják a lefelé görbülő szájat jelképező írásjelek számát az elégedetlenség kifejezésére, előfordul, hogy valaki ezekbôl tíznél is többet használ.

Gyakori még ezeken kívül az elhúzott szájat felidéző, és ezzel az indulatosságot kifejező | jel: >:| , illetve :-| vagy :| . Az elhúzott szájat szimbolizáló | jel helyett használják továbbá a / vagy a [ jelet tartalmazó >:/ , >:[ ikonokat is. Ritkábban találkozunk az eltúlzott

\}:-/IIIII/I// vagy :-[[[ formákkal. Az elégedetlenség érzékeltetésére is számos változata fordul elő a szájnak: : $[$, :7, :(), :-< , :O , :p , :S , :T , :-\#\#\#\# , :-c , :-e , :\$ . Több elem kombinálásával alkották a következő példákat: :-(| , :-(P .

Egyéni megoldásként fordul elô, hogy a nyolcas számjegyet választották a kigúvadt szem ábrázolására mind az indulatosság, mind az elégedetlenség jelzésére: 8( , 8-( . A vicsorgó fogakat a \# jel szimbolizálja. Érdekes egyéni variáció a @ jel alkalmazása a száj helyén. A :-@ ikon - elszigetelt előfordulása miatt - nehezen fejthetô meg, de valószínúleg az eltátott szájat, a kiabálást vagy a kinyújtott nyelvet szimbolizálja. Az elkerekített száj és az ezzel együttjáró kiabálás szimbolizálására a kis o vagy a nagy O betût használják: :o, halmozva: :oooooo, esetleg :oO .

A szimbólumok és az írásjelek kombinált használatára érdekes példák azok, ahol az üzenet küldője az emotikonnal kifejezendő érzelem nyomatékosítását halmozott felkiáltó jelekkel vagy kérdôjelekkel oldja meg: >://I/ !!!!!!! vagy :-|???? .

Elszigetelt esetekben előfordulnak bonyolultabb ábrákat adó egyéni variációk is: $8====0, \mathrm{q}>: 0\left(,:\left(\left(\left(\left(^{* * * * * ? ? ? @ * * * *}\right.\right.\right.\right.\right.$. 


\section{A boldogság és a vidámság kifejezése}

A boldogság és a vidámság nyelvi kifejezésére a kérdezett internetezők szinte kizárólag csak a mosolyszimbólumot használják, hiszen ez rendkívül egyértelmú, világosan kifejezhető érzelmi állapot, amelynek a jelölésére jól bevált, hagyományos szimbólumok vannak.

A pozitív emóciót egyértelmúen az alapvetô mosolyszimbólummal fejezik ki, amelynek nagyon sokféle változatát használják a válaszadók. Az viszont kiderül az adatokból, hogy a válaszok több mint felét a következő négy egyszerú, alapvetô smiley teszi ki: :) , :-) , :)) , :))) . A többi mosolykód jobbára már csak ezeknek a variációja, a mosolygó ajkat szimbolizáló ) jel halmozása. A mosolygó, szélesre nyílott száj kifejezésére a ) variációjaként használják a $\mathrm{D}$ és az o betût is: :D , :-D , :0) , :O. A vidámság szimbolizálására használják válaszadóim a $\mathbf{P}$ betút is::- $\mathbf{p},:-\mathbf{P}$, ez az elcsücsörített szájat, esetleg a kinyújtott nyelvet fejezi ki.

Figyelemre méltó, hogy van olyan internetezô is, aki nem rest speciális karaktereket alkalmazni egy-egy emotikonban, például: :Đ. Új elemként a vidámság kifejezésére megjelenik a haj jelzése is, § jellel: §:-)), §:))))))))), ez azonban elszigetelt jelenség, amit nem szabad általánosítani. Ez egyben azt is mutatja, hogy a mosolyszimbólumok ábrázoló funkciója igen erôs, és néha a gyorsan fellelhető jelek használata helyett nagyobb kifejezőerő kifejtésére, szövegalkotói kreativitásra motivál.

Elenyészốen ritkán fordul csak elô, hogy a válaszadók a fordított sorrendû, jobbra döntött fejet jelképező (-: emotikont alkalmazták, hiszen szinte törvényszerúnek tekintjük, hogy a szokásos :-) smiley balra döntött fejet szimbolizál. Az is előfordult, hogy az álló arcot szimbolizáló ^_ elcsoportot használták, ebben az esetben a szemet a ^ jelek, a szájat pedig a _ jel ábrázolja. Mindezeknek és a * jelnek a kombiná-

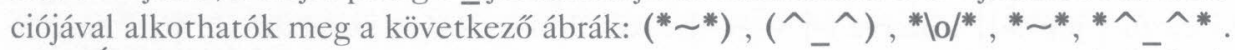

Újabb gazdagító elem a kicsorduló könnyet, esetleg a kacsintást szimbōlizáló ikon alkalmazása :'-) . A kifejezendô érzelmek nyomatékosítására itt is előfordul a felkiáltójelek halmozása az emotikon mellett: :)!!!! . A szem kiemelt szerepét mutatja, hogy az egyszerú kettôspont variációjaként előfordul a $\mathbf{B}$ betû́ vagy a $\mathbf{8}$ számjegy is: B) ,8-)) .

Feltétlenül megjegyzendő viszont, hogy az egyik válaszadó az erre alkalmazható emotikonok között, a vidámság és a pozitív érzelmi állapot szimbólumaként említette a rózsát utánzó : @-\}— ikont. A virág formáját a billentyưzet karakterkészletének elemeiból építette fel: a szirmokat a @ jel, a szárat a kötőjel, a levelet pedig a kapcsos zárójel ábrázolja, ezek a karakterek tehát együtt ikonikus jelet alkot, ami metonimikusan utal a vidámságra.

Nehezen elemezhető́k a következô egyéni variációk: =8-), @-> , d8-) , (.))) >> . A vidámság kifejezésére szolgáló emotikonok között említette egy válaszadó a vegyes összetételû d:-király jelzést, ami egyszerre tartalmaz képi funkciójú és nyelvi funkciójú elemeket: ennek szerzője nyelvi kóddal is megerôsítette a vizuális kódot.

\section{A türelmetlenség kifejezése}

A türelmetlenség olyan állapot, amit a válaszadók kifejezetten változatos eszközökkel fejeznek ki: közel egyharmaduk különböző írásjeleket halmoz. Külön kiemelendő, hogy itt a kérdôjel ismétlése a leggyakoribb. Súrún halmozzák a pontot, az alá- 
húzást, a kötőjelet és a csillagot is. A vizsgált internetező́k nem egészen egynegyed része fejezi ki szöveggel a türelmetlenségét, és ennél is ritkábban használnak ebben emotikont.

Nem jellemzô tehát, hogy türelmetlenségüket a válaszadók mosolyszimbólummal fejeznék ki internetes kommunikációjuk során, viszont azoknál, akik mégis ezt teszik, kifejezetten változatosak, kreatívak, tehát nincs egységes forma erre a célra; vélhetốen azért, mert ez összetett érzelmi állapot, olyan élethelyzet, amit nehéz szimbolizálni.

Leggyakrabban az elhúzott szájjal megjelenő :-I vagy : | emotikon jelent meg, a harmadik és a negyedik leggyakoribb szimbólum az elhúzott száj két másik formai variációja, a :/ és a :-/ volt. A száj formája a türelmetlenséget kifejező smiley-k esetében gyakran változik, a különféle formai változatokban gyakori az elkerekített (kiabáló) szájforma: :-o , :O , :o| , :-O , :o/ , <:O , :-D , :-PPP , :@ , :0O . Az elbiggyesztett, elégedetlenséget sugalló szájtartás érdekes kifejezési módja a következő: :-s , :-S , :s , :S .

Az elégedetlenséget, türelmetlenséget kifejező emotikonokat néha írásjelekkel, illetve betûsorokkal is kiegészítik: :RGGGGGG , : o ! , :! . Ezekben a ritkán előforduló, elszigetelt esetekben nagyon nehéz eldönteni, hogy a felhasznált karakterek ábrázoló vagy szimbolikus nyelvi funkciót töltenek-e be.

Érdemes megjegyezni, hogy a türelmetlenséget kifejező emotikonok legtöbb variációja a szájat szimbolizáló elemet módosítja, vagyis ennek az érzelmi állapotnak az egyik leghangsúlyosabb és legjobban variálható eleme a szájat jelképező karakter.

\section{A gúny kifejezése az Interneten}

A válaszadók véleménye szerint a gúny is elég jól kifejezhető valamilyen mosolyszimbólummal: legalább háromnegyed részük emotikonnal érzékelteti a gúnyos attitûdöt, árnyalatot. A gúny is egyértelmú érzelmi viszonyulás, kifejezése felerôsítésen, túlzáson alapul. Érzékeltetéséhez ugyanakkor mindenképpen szükség van szövegszerû kommunikációs kontextusra is, csak annak keretében lehet emotikonnal világosan, egyértelmúen jelölni. A mosolyszimbólum általában is csak kiegészítô elem, önmagában ritkán fordul elő, jellemzően szöveges elemekhez kapcsolódik, s ez fokozottan érvényes a gúny esetében. A válaszadók egynegyed része csak szöveggel érzékeltette üzenetének gúnyos jellegét.

A gúnyos jelentésú mosolykódok szintén nagy változatosságot mutatnak, hiszen a leggyakoribb elem is csak minden hatodik esetben jelenik meg (1319-ből): a :P vagy :-p szimbólum az elhúzott szájat, a kinyújtott nyelvet szimbolizálja. Ezek variációjaként a domináns elem halmozása is többször előfordul: :PPP. A gúny jelölésére szintén gyakran használják a mosolygós szájat: ;) , :-) , >:) , illetve ennek különféle változatait: :> , :D , :oP , :9, , ] , :- \} , :Đ. Ritkán megjelennek más szájtartást jelképezố jelelemek is: ;-V , >:-O , :-§, :-A , :-B , :1 , :D .

A gúnyt kifejező smiley megszerkesztéséhez felhasznált karakterek között rendszerint vannak kiegészítő elemek, amelyek az arc felsố részét, a szemet, a szemöldököt, illetve a homlokot jelképezik, s ezek azt mutatják, hogy az alapvetôen vidámságot kifejezó emotikon-elemeknek többletjelentésük is van, hiszen a gúny korántsem mindig vidám attitűd: >:) , \}:-) , ;)))) (pontosvesszővel jelölt kacsintó szem), ];-) , $=:-),(8-),=\mid,:-)=, x:), q ;]$. 


\section{Általános tapasztaltok az emotikonok használatáról}

Összefoglalóan olyan következtetéseket lehet levonni, amelyek árnyalhatják az emotikonok használatáról kialakult, sokszor közhelyszerú képet. Annyi mindenesetre megállapítható, hogy az érzelmek kifejezésére sokoldalú lehetőségek állnak rendelkezésre az internetes kommunikációban, és az emotikon a szöveges és a másfajta vizuális kifejezésmódokat csak megerősíti, kiegészíti.

Az emotikonok végtelenül sok egyéni változatban jelenhetnek meg, de az alapváltozatok a leggyakoribbak. Minél gyakrabban használják ezeket az alaptípusokat, annál egyértelmúbb, világosabb a bemutatandó, illusztrálandó érzelem. Az összetettebb érzelmek, állapotok, érzékeltetésére alkalmazták legkevésbé az emotikonokat: itt a szöveges kifejtés mellett a különféle írásjelek halmozása fordult elő a legtöbbször.

$\mathrm{Az}-\mathrm{az}$ általam ismételten hangsúlyozott tény -, hogy az alapvetố érzelmek kifejezésére az emotikonok legegyszerúbb alaptípusai fordultak elő a legnagyobb mennyiségben, viszonylag zárt szimbólumhasználati módra utal, ami könnyen, gyorsan elsajátítható és ugyanilyen könnyen értelmezhetố. Ugyanakkor az alkotóelemek variálására, halmozására korlátlan egyéni lehetőség nyílik, amivel élnek is a válaszadók, de ezek a formák nem tömegesek, megmaradnak hapax legomenon-nak. Az Internet jellegéból adódóan óriási lehetôsége van mindenkinek a tartalom - különösen az emocionális tartalom - hangsúlyozására a vizuális szimbólumok kreatív felhasználása segítségével.

\section{A közvetlen emberi kommunikáció és az internetes interakció}

Horányi Özséb gondolatmenete és megfogalmazása szerint az oralitástól kezdve az íráson át a számítógép közvetítette kommunikációig jelentősen megváltozott a kommunikátumok térbeli lokalizáltsága: az orális kommunikátum térben szigorúan lokalizált; az írásos feljegyzés ugyan lokalizált, de nem szigorúan, mert szállítható, másolható; a számítógépes hálózaton megjelenő kommunikátum voltaképpen nem lokalizálható. Megváltoztak a kommunikátumok elérhetővé tételének a módszerei, és jelentôsen lecsökkent az elérési idô is: az orális kommunikátum elillanó természetú, az írott (nyomtatott) információk személytelenebbek a beszédnél és maradandók, viszont térben korlátozottak, míg a számítógépes hálózat által elektronikus úton közvetített kommunikátum szinte már a létrehozása pillanatában eljuthat a tér bármely pontjára. Megnövekedett az adott információt (a kommunikátumot) közvetlenül elérni képes befogadók száma is, hiszen a szóban elmondott szöveget csak a jelenlévốk percipiálhatják, míg az írott és különösen a nyomtatott szöveget akár már nagy tömegek is elérhetik változatlan formában, a számítógépes hálózat közvetítette kommunikátumok pedig gyakorlatilag azonnal, még a nyomtatásban terjesztett közleményeknél is több potenciális címzettet érhetnek el, (Horányi, 1997). ${ }^{6}$

${ }^{6}$ http://www.mek.iif.hu/porta/szint/human/media/hozseb1/hozsb1.mek 


\section{Csevegőfórum mint az internetes interakció csúcsa}

Az Interneten létrehozott csevegőfórumok időfüggőek, azonnali válaszlehetôséget kínálnak és az azonnali befogadás, válaszadás igényét hordozzák, hasonlóan a közvetlen emberi kommunikációhoz (vö.: Buda, 1994). A hálózati interakció javarésze viszont elsôsorban írásban jelenik meg (Crystal, 2001:29).

A csevegőfórumok biztosítják a leggyorsabb lehetőséget az Internet közvetítésével folytatott kommunikációhoz. Az üzenet itt az élőbeszéd sebességétől alig-alig elmaradva jut el a befogadóhoz. Ezeknek a csevegófórumoknak a nyelve közelít a legjobban az élő beszélt nyelvhez, illetve annak egyes csoportnyelvi változataihoz. Christopher C. Werry számos csevegőfórumon végzett vizsgálatai alapján a következő megállapítást teszi: „Az IRC (Internet Relay Chat, internetes csevegés) formájában megvalósuló kommunikációt jelentős mértékben a közvetlen emberi kommunikáció, a beszélt nyelv reprodukálásának igénye motiválja" (Werry, 1996:61). Werry a csevegőfórumok kommunikációját ennek megfelelően - mivel a csevegés két vagy több személy között az élôszó szinkronitásával, de írott formában folyik - interaktí írott diskurzusnak nevezi (Werry, 1996:47).

Egy-egy csevegôszobában egyidejưleg sok írott párbeszéd zajlik egy helyen és egy időben. Kevés az olyan párbeszéd, ami a csevegôszobában egymás utáni megszólalások összefüggő sorozataként jelenik meg, hiszen egyszerre többen folyatatnak dialógust, és minden egyes megszólalás akkor tưnik fel a mindenki által látható képernyôfelületen, amikor azt a résztvevố leírta és egy gombnyomással elküldte a fórumra.

A csevegőfórumok dialógusainak felépítése tehát nem egyezik meg egyik korábbi kommunikációs műfajjal sem, nagyon hasonlít a spontán beszélt nyelven folytatott párbeszédhez, viszont annál szervezetlenebb és tartalmilag nagyon hiányos, továbbá gyakran hiányzik belőle a makrotervezés minden eleme. A szervezetlenséget ugyanakkor kompenzálja a szöveg írásbeli, statikus megjelenési módja, s ennek segítségével mégis követhetô valamelyest a párbeszéd fonala. Ez a kommunikációs múfaj lehetôséget ad a valós idôben folytatott párbeszédre egymástól térben igen távol elhelyezkedő résztvevők között, s a hagyományos írásbeliségnél összehasonlíthatatlanul gyorsabb kommunikációt biztosít számukra.

$\mathrm{Az}$ Interneten megjelenô szövegek - fốleg az erôsen interaktív chat fórumokon és az e-mail üzenetekben, de a hálózati honlapokon is - egyre inkább vázlatszerűek, s mind szerkezetüket, mind formai kivitelezésüket tekintve távolodnak a hagyományos írásbeliségtôl. Jakob Nielsen szerint mindez azért van így, mert a honlapok szövege is kezd alkalmazkodni ahhoz, amit magyarul - Nielsen nyomán, jobb híján - „internetes olvasásnak” (webreading), esetleg „képernyő-olvasásnak” nevezhetünk. Az Interneten az olvasók nem lineárisan haladnak előre az olvasásban, hanem „szkennelnek”, vagyis egyes szavakat, szerkezeteket emelnek ki a szövegból (Nielsen, 1997). ${ }^{7}$ Emiatt a szerkesztés is a könnyű, gyors értelmezhetőséget célozza meg, hasonlóan a spontán beszélt nyelvhez, ahol az egyidejűség, az interaktivitás, a pillanatnyiság érdekében ugyanilyen igényeknek és elvárásoknak kell megfelelni.

\footnotetext{
${ }^{7}$ http://www.useit.com/alertbox/9710a.html
} 
Sok közös vonást lehet találni a spontán élóbeszéd és a spontán elektronikus levelezés, illetve a csevegőfórumokon megjelenő szövegek tervezési és kivitelezési folyamatai között is, annak ellenére, hogy az elektronikus levelezés alapja mégiscsak az írott szöveg. Az elektronikus levelezésben és az internetes csevegésben a szövegek megformáltsága a hagyományos írott levelekéhez képest gyenge, s gyakran teljesen hiányzik a korrekció.

A ,netnyelv” általában közelebb áll az írásbeliséghez, de sok beszédsajátosságot hordoz, és David Crystal is elismeri, hogy ez múfajonként más és más: a chat, majd az e-mail nyelve van a legközelebb a beszédhez, míg a hálózati portálok, a honlapok nyelve áll a legtávolabb attól (Crystal, 2001:47).

A hálózati interakció és a közvetlen (face-to-face) emberi kommunikáció legfóbb különbségei Crystal szerint az alábbiak:

- Az azonnali (szimultán) és kölcsönös visszajelzés hiánya, ami abból ered, hogy az üzenet csak ideális esetben jelenik meg azonnal a címzett képernyójén, és a fogadó fél csak ritkán tud azonnal válaszolni, mert ehhez a bekapcsolt gépnél kell lennie, el kell indítani a megfelelốprogramokat stb. (Crystal, 2001:30). (Ehhez a magam részéról hozzá kell tennem, hogy az Interneten az üzenetváltás ritmusa valamivel lassúbb ugyan, mint a valódi párbeszédben, ez mégis sokkal közelebb áll a beszédhez, mint a hagyományos írásbeliség.)

- Ha sokan vannak egy csevegószobában, akkor óhatatlanul belebeszélnek egymás párbeszédébe, s a diskurzus szálai összekeverednek (Crystal, 2001:32).

- Ha valaki egy chat fórumon lassan válaszol, akkor az interakció nem történik meg, a párbeszéd fonala visszajelzés nélkül megszakad (Crystal, 2001:32).

- Sok felhasználót kiszolgáló környezetben az üzenetek egyszerre több forrásból érkeznek, így a párbeszéd egyszerre több irányban zajlik, és a szünetek beiktatása, illetve a szálak megszakadása is jóval gyakoribb, mint a közvetlen emberi kommunikációban (Crystal, 2001:33).

\section{Következtetések}

Az internetes nyelvhasználatról általánosságban kevés állítást lehet megfogalmazni, inkább csak egyes kommunikációs műfajok nyelvhasználatáról szolgálhatunk konkrétumokkal.

Az írásbeliségben hagyományosan igen fontos megformálási és kivitelezési szabályrendszer az Interneten folyó interakciókban általában sokkal kevésbé jelentôs. Az alapvető helyesírási és kivitelezési normáktól való eltérés az esetek túlnyomó többségében nem tudáshiányból, hanem a korrekció esetleges elmaradásából vagy a nyelvi elemek szándékoltan eltérő, önálló, kreatív használatából, valamint az emocionalitás, a csoportnyelvi hovatartozás és a vizuálisan jobban érzékeltethetô mondanivaló kifejezésre juttatásának szándékából fakad.

Az internetes interakciók során gyakori a rövidítések, a smiley-k és az egyéb írásbeli szimbólumok igénybevétele. Ezekkel a módszerekkel a levelező partnerek és a csevegốk a paralingvisztikai, metanyelvi elemeket kívánják pótolni az írásbeliség ke- 
retei között, és az élőszóval összemérhető tempójú interakciót próbálják minél jobban megközelíteni.

Mindebből az következik, hogy az Interneten az írott beszélt nyelv szövegei fokozatosan módosulnak és elszakadnak a hagyományos írásbeliségtől, s bizonyos jellemzóiket tekintve inkább a szóbeliséghez közelítenek. A poszt-Gutenberg galaxis korában figyelemre méltó változáson megy keresztül a magyar nyelv is, hiszen az írott nyelv a világhálón több szempontból is egyre határozottabban a beszélt nyelvhez idomul, míg Bárczi Géza szerint a felvilágosodás korában az egységesedő magyar társalgási nyelvnek még az igényes szépirodalmi írásbeliség volt az alapja (Bárczi, 1996:327-328).

\section{IRODALOM}

Babbie, Earl (1999): A társadalomtudományi kutatás gyakorlata. Balassi Kiadó, Budapest. Balázs Géza (2003): „Minden házfalat cseréljetek sms-falra”. Sms-fal mint elektronikus graffiti. Magyar Nyelvốr, 127: 144-158.

Bárczi Géza (1996): A magyar nyelv életrajza. Custos Kiadó, Budapest.

Bódi Zoltán (1998): Internetes kommunikáció - beszédkommunikáció. In: Gósy Mária (szerk.). Beszédkutatás '98. Beszéd, spontán beszéd, beszédkommunikáció, 178-188. o. MTA Nyelvtudományi Intézete, Budapest.

Bódi Zoltán (2004): A világháló nyelve. Internetezők és internetes nyelvhasználat a magyar társadalomban. Gondolat Kiadó, Budapest.

Buda Béla (1994): A közvetlen emberi kommunikáció szabályszerüségei. Animula Kiadó, Budapest.

Collot, Milena - Bellmore, Nancy (1996): Electronic Language: A New Variety of English. In: Herring, Susan C. (ed.): Computer-Mediated Communication. Linguistic, Social and Cross-Cultural Perspectives. Pragmatics छृ Beyond. New Series 39.:13-28. John Benjamins, Amsterdam.

Crystal, David (2001): Language and the Internet. Cambridge Univetsity Press, Cambridge.

Dyson, Esther (1998): 2.0 verzió. Életünk a digitális korban. HVG Kiadó, Budapest.

Ferris, Pixie (1997): Writing In Cyberspace. CMC Magazine, June, 1997.

http://www.december.com/cmc/mag/1997/jun/ferris.html

Harnad, Stevan (1990): Scholarly Skywriting and the Prepublication Continuum of Scientific Inquiry. Psychological Science, 1990/1:342-343.

http://cogsci.soton.ac.uk/ harnad/Papers/Harnad/harnad90.skywriting.html

Heim, Michael (1997): Virtual Reality and the Tea Ceremony. http://www.mheim.com/html/docs/vrtea/vrtea.html

Herring, Susan C. (1996): Introduction. Computer-Mediated Communication. Linguistic, Social and Cross-Cultural Perspectives. Pragmatics \& Beyond. New Series 39. (ed.) 1-10, John Benjamins, Amsterdam.

Horányi Özséb (1997): Az információs társadalom koncepciójától az információ kultúrája felé. http://www.mek.iif.hu/porta/szint/human/media/hozseb1/hoz sb1.mek 
Kis Ádám (1997): A számítógép metakommunikációja. A beszéd, az írás és a számítógépeskommunikáció. (Előadás, elhangzott a VII. Országos Alkalmazott Nyelvészeti Konferencián), Budapest. http://www.mek.iif.hu/porta/szint/tarsad/nyelvtud/szmtgps.hun

Koltay Tibor (1997): Az e-mail üzenetek pragmatikai jellemzôirôl. In: Petőfi S. János - Békés Imre - Vass László (szerk.) Szemiotikai szöøegtan 10. pp. 91-97. JGY'TF, Szeged.

Márton Sándor (2000): A számítógép a szociológiai kutatásokban. Magyar Tudomány, XLV, 10. szám, 1240-1241.

Miklós Kata (1996): Az IRC nyelvezete.

http://www.mek.iif.hu/porta/szint/muszaki/szamtech/wan/kultura/ircnyelv.hun

Nielsen, Jakob (1997): How Users Read on the Web. http://www.useit.com/alertbox/9710a.html

Nyíri Kristóf (1996): Bölcsészettudományok az írásbeliség után. Világosság, 1996/6.:3-16.

Ong, Walter (1982): Orality and Literacy. The Technologizing of the Word. Methuen, London - New York

Szépe György (1997): Az Internet-korszak nyelvészete. Modern Nyelvoktatás III., 1997. május. pp. 76-89.

The Unofficial Smiley Dictionary. EFF's (Extended) Guide to the Internet. http://www.ece.umr.edu/general/Internet_Users_guide/eeg_286.html\#SEC287

Werry, Christopher G. (1996): Linguistic and Interactional Features of Internet

Relay Chat. In: Herring, Susan C. (ed.): Computer-

Mediated Communication. Linguistic, Social and Cross-Cultural Perspectives. Pragmatics \& Beyond. New Series 39. pp. 47-63. John Benjamins, Amsterdam.

Yates, Simeon J. (1996): Oral and Written Linguistic Aspects of Computer Conferencing: A Corpus Based Study. In: Herring, Susan C. (ed.): Computer-Mediated Communication. Linguistic, Social and CrossCultural Perspectives. Pragmatisc \& Beyond. New Series 39. pp. 29-46. John Benjamins, Amsterdam. 